\title{
The Arising Uncertainties from Democratization Process in Arab Spring Countries
}

\author{
Khemis Mohamed \\ Assistant professor in future studies \\ Department of Political Sciences, Faculty of Law and Political Sciences \\ Université Kasdi Merbah-Ouargla Algérie
}

\author{
Doi:10.5901/mjss.2013.v4n10p443
}

\begin{abstract}
After one or two years of the remarkable transformations in the Arab world which toppled some of the most resilient authoritarian regimes in the world however, the democratic transition process seems gloomy, uncertain, unstable, and chaotic in some cases (Yemen, Egypt, Libya). This study aims to explore the supposed multiple futures of the Arab Spring without the exclusion of failure scenario, in lights of the following assumptions: First: is that the existence of uncertainties are the key elements to the possibility of successful democratic transition; Second: the transition process assumed to be elite led, or even under the presence of repressive elite that has interests to liberalize and democratize during transition period.
\end{abstract}

Keywords: Arab Spring countries, Democratization processes, Democracy consolidation, Uncertainties.

\section{Introduction}

Two years after the political upheavals that swept through the Arab world and the answers to fundamental questions remain unsatisfactory, over two years of democratization processes in Arab Spring countries, wide range of political and socio-economic uncertainties have been escalated dramatically. The ultimate aim of the Arab spring countries was to attain a successful transition to democracy but the disruption which associated with high degrees of uncertainties in political and social arena poses serious challenges and threatened the fragile advancement in transition processes.

Regardless, of the complex puzzle of multiple uncertainties emerging in Arab spring countries, we argue that, there is a huge opportunity to build a consolidated democracy in this region. This paper tries to explore the key uncertainties and "wild cards" within democratization process in Arab Spring countries through different approaches of comparative politics.

The central thesis in this paper is test the validity of one-scenario driven studies of democratization literature, these type of literature assume that, there is one way process of regime change, from authoritarian to democracy. Since the paradigm shift in studies of democratization in late 1950s, when Symour Martin Lipset set out the economic and political perquisites of democracy. But, the failure in democratization and chaotic outcomes in some cases reminds us that democratization is very complex and non-linear process.

It could be argued that the Arab Spring was seen as unified phenomenon swept the Arab world. However, past experiences show that even in throughout inspired or triggered by external events unfold in accordance with their own particular dynamics. Thus, this study aims to illustrate the exceptionality of each individual case of the Arab Spring countries.

\section{Democratization uncertainties in comparative politics literature:}

Democracy, among some other phenomena seems as mega trends that will shape the future of humanity for a long time such, globalization, technology, and urbanization. Actually the democratization has been flourished as set of processes to rationalize the political mainstream, or, it means the whole process to political system change over the last four decades. In 1973 according to Freedom House report, rated just 29 of 151 countries as "free," 28 percent as "partly free," and 43 percent as "not free." By the end of 2011 the percentage, the percentage of free and not free countries has roughly reversed, 45 of 195 countries were free, 31 percent were partly free, and 24 percent were not free.

There is a consensus among scholars about the linear development toward setting democratic values but, the key uncertainty about democratization rely on the notion of "transition paradigm", and the lack of certainty whether, the move 
from authoritarian rule to a democratic regime is secured process to build a stable democracy. The phases of change which represents neither authoritarian rule nor democracy, and refers to a "gray zone", "puzzle" or rather "uncertainty".

Adam Przeworski (1991) in his book "Democracy and Market" tried to analyze the key question of uncertainty and democracy, he asked about the contending agendas of post-authoritarian regime stakeholders especially, the winners and losers of democracy's new era: Why would the losers choose to comply with the results?

He argued to include the possibility of two types of uncertainty that are particularly relevant in Middle East countries:

The first is uncertainty in the part of civil society regarding the willingness the regime liberalizers to repress; the second involves the uncertainty of regime liberalizers regarding civil society commitment to democracy.

In this context, przeworski (1991) emphases the fact that, the uncertainty on the part of liberalizers regarding to type civil society that it faces is an important part of the political landscape in the contemporary Islamic associations in the Arab world which are best organized and the most important civil society groups (e, g., Muslim Brotherhood in Egypt).Thus, he suggests a number of key finding: The first is that the existence of uncertainty is key to the possibility of for democratic transition, and he argued that to democracy occur under a wide range of different variables.

Second, transition to democracy is only possible when the repressive capacity exceeds certain threshold. Hence, in this given conditions, democracy cannot occur only when regime liberalizers who prefer democracy narrowed dictatorship, and interact with civil society that will honor democratic values and principles (Przeworski, 1991).

However, (Miller, Martini, Larrabee, Rabassa, Pezard, Taylor, Mengistu, 2012), described the transition uncertainties by using the notion "gray zone" that have been settled into many countries of divers form of government where autocratic and democratic measures are combined. Such countries in "transition" are no longer seen as simply stalled on the of democracy, thus, the notion of "grey zone" or "transition" refers to non-linear criteria of democratization process, which it can be influenced the outcomes for how it can unfold. Furthermore, Miller et al (2012) supposed that the underway dramatic changes in the Arab world may lead to various possible futures and destinations, that may be differ extremely from their points of departure.

Moreover, such wide range of uncertain futures about democracy appearance would raise new questions concerning structural conditions of democratization process in Arab spring countries. Such as: the mode of regime change; the country's past experience with political pluralism; critical policy choices; state and social cohesion; economic characteristics; the external environment; external policy choices and assistance, Including efforts by foreign actors to foster democratization.

Otherwise, among other scholars and researchers in democratization literature who thought that, democratization is the only outcome of wild cards of civil wars, and they argued that, democracy quite often arises from civil wars. Using measures of democracy provided by Jaggers and Gurr (1999), and civil war data provide by Lickilder (1998), Nickerson (2001) find that nearly forty percent of all civil wars that took place from 1945 to 1933 resulted in an improvement in democracy, including some Arab countries such Algeria, with countries like Mozambique, El- Salvador, Liberia, Guatemala and Nicaragua whom experienced civil wars.

But, there are a series of influential studies that explain deeply the sources of uncertainty within democratization process, and they argued that the suppression of democracy in some cases comes about duo to recourses holder's fear of what those who win democratic elections will do, this fear is what Egyptian liberals and Copts, felt after Freedom and Justice "the Islamic" party came to power, together with radical Salafist Nour Party they dominated parliament with over $70 \%$ of all seats in democratic legislation elections. (Meltzer and Richards, 1981) This assumption is related with studies which focused on the impact of democracy on the forms of economic distribution (Acemoglu and Robinson, 2006; Boix, 2003; Ziblatt, 2008), and shared the same theoretical departures with whom they argued that democracy would yield the ideal point of the median voter, which would be involved in economic redistribution, or the "progressive" approach that consider economic development as development that is designed to result in wide distribution of the benefits of growth, significant and sustained improvement in the quality of life of the population, and admitted a simple idea "The poor are numerous".

As parties compete for electoral support they have an interest in adopting policies that favor the interests of the poor." In other words, democratization process boils down to a battle over economic interests between political actors (Przeworski, Alvarez, Cheibub, Limongi, 2000).

There have a number of attempts to explain the spectrum of uncertainties in the face Middle East and Arab countries under democratization, or countries that are still resisting to any kind of democratization (before the uprising of Arab spring) (Salame, 1994), Lisa Blaydes and James Lo (2011) summarize the themes of the Middle Eastern exceptionality into three groups of theories: 
- Structural economic explanations

- External factors

- Political culture and civil society

Samuel Huntington made further points in his remarkable book "Political Order in Changing Societies", to analyze higher degrees of uncertainty, by using the notions of "political decay, or a decline in political order" that threatened the transition process from authoritarian rule to democracy, he suggested that these type of uncertainties and wild cards refers to "an undermining of the authority, effectiveness, and legitimacy of government". Thus, the central thesis in Huntington's work is to understand the sources of instability and uncertainty that was in large part the product of rapid social change, and the rapid mobilization of new groups into politics coupled with slow development of political institutions (Huntington, 1968).

To avoid democratization failure and the risk of uncertain long-term processes, Valenzuela noted that there are two phases in democratic transitions must be involved. First begins with severe crisis of the authoritarian regime raises the possibility of substituting it with democratic regime chosen by democratic measures. Second begins and ends at the point when the fledging democratic regime is consolidated. In Valenzuela (1990) view, democratization process will be easier to consolidate just in following conditions:

1. When the authoritarian rule is removed quickly.

2. When he is repudiated not only by his opponents but also by his supporters.

3. When most old supporters of the authoritarian regime become willing participants in the democratic transition process and are fully accepted as players in it by their opponents.

4. When the transition to elections is handled by a provisional government led by civilian elites rather than the military.

5. When the state-including the military-does not disintegrate but continues to function and the military focuses narrowly on its national security concerns.

6. When organized segments of civil society-including religious leaders in countries in which social cleavages linked to religion are important-have fluid forms of dialogue and forge agreements to find common ground on critical issues that concern them.

7. When the period of the first transition is relatively short. It should be long enough to make sure that the coming electoral process will indeed be free and fair, and that all players will trust that the votes will be properly counted.

8. When the drafting of the new democratic constitution occurs after the inauguration of the newly elected government and legislature and is approved in a specially convened plebiscite devoted exclusively to this matter.

9. When the national judicial system takes charge of prosecuting human rights violators without direct political initiative or interference.

10. When politically pluralistic fact-finding commissions of experts are officially appointed to investigate past crimes and conflicts associated with and leading up to the authoritarian regime. The result should be to forge a single widely accepted narrative of the past.

11. When pragmatic or moderate political leaders can create or recreate parties that will capture a large majority of votes while expressing the views and policy preferences of all major components of the national society (Kellogg Institute for International Studies, 2012).

Yet, overall discussions above, it seems that democratization literature were one-scenario driven studies, of one way process regime of change, from authoritarian to democracy. Since the paradigm shift in studies of democratization in late 1950s, when Symour Martin Lipset set out the economic and political perquisites of democracy. But, the failure in democratization and chaotic outcomes in some cases reminds us that democratization is very complex, non-linear process, which Guilermo O'Donnell and Thomas Carothers have pointed out that: "It does not have an end" (Galbreath, 2012).

David J. Galbreath among other scholars confirmed the fact that comparative politics approach to democratization is problematic in both its concentration on agency and domestic political actors. Rather, he suggested the importance of structure as driver in democracy building, (e, g.,) Juan L. Linz and Alfred Stepan find that "structural elements of the prior regime have an important impact on regime paths and consolidation tasks." (Galbreath, 2012) Alfred Stepan and Juan Linz (2013) have illustrated also the fuzzy democratization process in Arab world as a new type of political regimes. They propose "the authoritarian-democratic hybrid" which represents a newly emergent phenomenon seen today in Arab world. 
According to Alfred Stepan and Juan Linz (Alfred Stepan and Juan Linz, 2013) "The authoritarian-democratic hybrid" refers to the unusual conditions so labeled: "They are places where most major actors believe that they will lose their legitimacy and their followers' support they fail to embrace certain features of democracy."

Furthermore, the debate of uncertainty of democratization processes in Western Countries, and the spreading of democracy toward Latin America and post-communist countries renew the same questions to geographical location that seems incompatible with democracy and liberal values. Before Arab spring uprising (that means the second wave of democratization in Arab world), after the first which known in the democratization literature as "third wave" that had began in 1970s in Eastern Europe and Latin America and moved toward Southeast Asia, Sub-Saharan, Maghreb and the Middle-East in the early 1990s, has proved a set of difficulties and uncertainties appeared during the process. David J. Galbreath (2012) summarized those explanations as follows:

- Firstly, the rarity of successful democracies in the Middle-East and Arab region made the application of the notions "transition" then "consolidation" quite difficult;

- Secondly, the statehood weaknesses in Middle-eastern countries that are still challenged by other forms of state-like entities (tribes, monarchies);

- Thirdly, the heterogeneous correlation between international politics and democratization processes.

On the other hand, there are a category of theories holds that the Arab world lacks cultural perquisite. Another group of theories look on what is exceptional in the Arab region, while others focused on the oil presence factors in the Arab region, and the oil revenues that enable authoritarian regimes to reinforce their power by distributing patronage. However, many of these conflicting diagnoses of democratization deficits in Middle-east and Arab region fail neither to explain, nor to predict the dramatic changes that prevail in the early of 2011 in Tunisia, and moved rapidly with snowball effect to many other countries in Arab region.

Finally, democratization literature has drawn three important findings:

- First, democratization is very complex, non-linear process;

- Secondly, democratization in the Middle-East and Arab region made the application of the notions "transition" then "consolidation" quite difficult;

- Thirdly, there are conflicting explanations of democratization's difficulties in Arab world, and the most of these explanations failed to explain or predict the Arab spring.

\section{Arab spring: democratization new contexts versus new uncertainties}

In applying democratization literature to Arab spring transition we find two relevant approaches. First of those scholars who argued that democratization has clustered geographically and that countries are far more likely to undergo transition following transitions in neighboring states. Those scholars pointed out that domestic political dynamics are deeply affected by changes in neighboring states. Secondly, others such Przeworski model has found that, democratization cannot find its way to diffuse without the whole commitment of domestic players.

The Arab spring has proved also that, current experiences exhibit significant variations from the "third wave" experiences to democratization, thus it has establishes a new paradigm that blown away a set of common assumptions about democracy in Arab world. Firstly, that authoritarian regime in Arab world were inherently stable; secondly, that democracy aspirations were unsustainable because the large Arab populations were culturally inclined to authoritarian rule; thirdly, that any of organized opposition to ruling regimes should be Islamist and undemocratic in nature; fourthly, that political demands of people of the Arab world were fundamentally different from people elsewhere; that any meaningful political change would have to become from the external actors (Willis, 2010).

The series of dramatic changes that launched in the early months of 2011 in Tunisia and Egypt had toppled some of the most resilient regimes in the Arab region, these changes have prevailed the uncertainty and the fragility of political legitimacy of Arab regimes, raises the question whether lessons drawn from previous democratization wave (Third wave). Hence, The Bertelsmann Stiftung's Transformation Index shed light on emerging political and economic deficits and uncertainties in countries of Middle East and North Africa in recent years. The BIT pointed out further explanations to the limits of economic improvement, which effectively confined to Arab countries under democratization process.

The BIT data contain considerable evidence of wide range difficulties released just after the moves toward democratizations and economic liberalization in the early of 2000s (Völker, 2012). Moreover, the BIT has found out a set of similar uncertainties, despite of the existence of considerable differences in terms of sociopolitical contexts. In particular, six countries most affected by Arab spring transformations, that is, Tunisia, Egypt, Libya, Yemen, Syria and Bahrain (Völker, 2012). 
Libya and Bahrain, for example are classic rentier states that derive majority their government fund from non-tax sources of revenue such as oil and gas exports, whereas countries like Egypt and Tunisia they have not such a resource base. Despite of, some other studies that found that there is no threshold of economic development is required for democratization, even in poorer countries on the whole tend to have weaker institutions, it is apparent that democratization can occur even with low level of economic and institutional development (Miller, et al, 2012).

Economic and social uncertainties have been escalated in Arab spring, and Arab countries in transition including Jordan, Morocco, and Bahrain.

Egypt for example, was facing serious economic challenges because the erosion in investor confidence and the tension in political and social arena remain high despite of democratic presidential elections. Tunisia also, was experiencing social and economic disruptions associated with fundamental political transition toward democracy. Thus, Jordan, Morocco, and Yemen have seen varying degrees of economic and social dilemmas during advancing political transition process.

Khandelwal and Roitman (2012) in their study "The economics of political transitions: implantations for the Arab spring" suggested that political transitions in Arab countries are characterized by intense political instability which is manifesting through changes in government, and large scale of socio-economic unrest. However, Khandelwal and Roitman (2013) made more contrast over similarities of Arab spring countries and European countries that have experienced two types of simultaneous transitions. First was political transition from authoritarian rule to democracy. Second was escalation in socio-economic unrest. Though, they find out that existing literature offered limited information about near-term, whereas they were to tend to offer more information about democratization success. Particularly, most of Arab spring countries are facing different degrees of near term social, economic and political instability.

In effect, the political instability associated with economic impact have been limited in countries such Jordan and Morocco, but countries such Egypt, Tunisia and Yemen have seen a high intense of political and economic instability.

Khandelwal and Roitman (2013) have used Cross-National Time Series (CNTS) data archive that has been identified political crisis in low-middle income countries, whether the political crisis led to democratization or to political decay since 1980 (see table1). The comparison between Arab countries and sample of 11 countries in CNTS, which exclude European transition economies and oil exporting countries, asserted that social unrest occurred on large scale with sever political instability.

Table 1: Political Instability Events Since 1980

\begin{tabular}{|l|c|c|}
\hline & Political crisis & Government change \\
\hline Albania & $1997-98$ & Yes \\
\hline Argentina & $2001-03$ & Yes \\
\hline Cote-D'Ivoire & $2000-01$ & No \\
\hline Honduras & $2009-10$ & Yes \\
\hline Korea & $1980-81$ & Yes \\
\hline Madagascar & 2002 & Yes \\
\hline Myanmar & $1988-90$ & No \\
\hline Paraguay & $1999-03$ & Yes \\
\hline Philippine & $1983-87$ & Yes \\
\hline South Africa & $1990-94$ & Yes \\
\hline Togo & $1991-93$ & No \\
\hline
\end{tabular}

Source: Padamja Khandelwal and Augustin Roitman (2013) The Economics of Political Transition: Implications for Arab Spring, IMF, Working Paper 13/69

Note that, it is very important to make clear distinction between Arab spring countries because there are significant differences in conditions, challenges and even the motives behind each country's uprisings. For example, unlike Egypt and Tunisia which have a very robust civil society that was prior to democratic transition, civil society in Libya is nonexistent, and the revolution in Libya was more of domino effect, and the Libyan people were not able to overthrow the authoritarian rule without the external intervention from NATO (Boose, 2012).

If we compare the situation in Libya and Tunisia or Egypt based on three critical criteria; regime, state and civil society, and the strength and weakness of each of these three criteria, we can conclude that Libya is likely to fail in 
democratization process because of its weakness in these three criteria, whereas Egypt and Tunisia are more likely to have a successful transition to democracy, were there is a strong bases for state, regime and civil society (Boose, 2012).

Libya will need to build a solid framework for governance and institutions of civil society, contrary to Egypt and Tunisia. Libya will face a much complicated problems of weak internal cohesion, given tribal and regional splits within the country (see table 2). Yemen also has a tribal society and riven by internal divides, with pockets were the central government has essentially ceded the control. However, unlike Libya, the emerging political transition in Yemen appears to share important characteristics with some successful democratization experiences because, in the early of 2012, Yemen had initiated the type negotiated or pacted, transition seen in Latin America cases, as well as in Spain. (Miller, et al, 2012).

Table 2: Civil society organizations in Libya and Tunisia

\begin{tabular}{|l|l|l|}
\hline Civil Society Organizations & Libya & Tunisia \\
\hline Comparing Tunisia and Libya & 28 & 101 \\
\hline $\begin{array}{l}\text { Number of UN recognized civil society } \\
\text { organizations in each respective country }\end{array}$ & 28 & \\
\hline
\end{tabular}

Source: Jason William Boose, «Democratization and Civil Society: Libya, Tunisia and the Arab Spring, » International Journal of Social Science and Humanity, (Vol. 2, No. 4, July 2012), 310-315

In fact, the major challenge in Yemeni political transition is democracy consolidation within center-periphery dynamics, unlike Tunisia and Egypt, Libya and Yemen will need to overhaul the structure of government and adopt a federal model that offers autonomy to its periphery in return for support for state institutions.

In case of Syria, Miler et al (2012) argued the possibility of applying the same lessons of Tunisia's case, especially if authoritarian Syrian regime falls, the likelihood of precipitant factors will be largely evident by the Syrian army and the regime's elite internal security forces. Those factors along with the fact that power vacuum could transform Syria into arena of civil war and regional proxy conflict.

\section{Conclusions}

Finally, it could be argued that transition to democracy in Arab Spring countries still seems fragile and uncertain, the Arab young protestors in Tunisia, Egypt, Libya and Yemen were unified about the desire to overthrow the authoritarian rule, but they are uncertain about what should come next. Most of Arab Spring analysts have been noticed that Egypt and Tunisia shown strong ability to build successful democracy in Arab world, but over the past two years, both of Egypt and Tunisia consistently appeared in state of disorder and chaos, with high levels of political uncertainty. However, the current comparative politics literature argued that we should recognize the long-term nature of democratization, and the consolidation of democracy if it occurs in Arab spring countries is likely to take many years.

Yet, the democratization literature typically describes the transition to democracy in Arab gone through two different phases. Both of these two phases are characterized by high degrees of uncertainties:

The "Third wave" phase that had begun in Arab world in the early years 1990s, proved a set of difficulties and uncertainties appeared during the process, three types of theories have been discussed this first phase, and argued that: there are a category of theories holds that the Arab world lacks cultural perquisite. Another group of theories look on what is exceptional in the Arab region, while others focused on the oil presence factors in the Arab region, and the oil revenues that enable authoritarian regimes to reinforce their power by distributing patronage. The first phase of democratization in Arab world was also characterized by the following aspects:

- Firstly, the rarity of successful democracies in the Middle-East and Arab region made the application of the notions "transition" then "consolidation" quite difficult;

- Secondly, the statehood weaknesses in Middle-eastern countries that are still challenged by other forms of state-like entities (tribes, monarchies);

- Thirdly, the heterogeneous correlation between international politics and democratization processes.

The "Arab spring" phase of democratization in Arab world has been launched as wild card event in early months of 2011. Democratization literature during this phase has shown two relevant approaches. First of those scholars who argued that democratization has clustered geographically and that countries are far more likely to undergo transition 
following transitions in neighboring states (contrary to third wave view). These scholars pointed out that domestic political dynamics are deeply affected by changes in neighboring states. Secondly, others such Przeworski model has found that, democratization cannot find its way to diffuse without the whole commitment of domestic players. Despite of the absence of consensus about democratization processes in Arab region, the Arab Spring phase has drawn some of the same of the first phase's set of difficulties and uncertainties:

- First, democratization is very complex, non-linear process;

- Secondly, democratization in the Middle-East and Arab region made the application of the notions "transition" then "consolidation" quite difficult;

- Thirdly, there are conflicting explanations of democratization's difficulties in Arab world, and the most of those old explanations failed to explain or predict the Arab spring.

In sum, democracy consolidation seems the most desirable outcome in Arab Spring countries but, scholars such Valenzuela has mentioned eleven conditions to consolidate democracy in Arab world thus, there is no simple way to gather all those conditions in one case.

Regardless, of the wide range of uncertainties and hurdles those are facing the Arab Spring countries, mega trends worldwide and within the region have been toward greater democracy, even in places that were once regarded as infertile ground.

\section{References}

Acemoglu, Daron and Robinson, James. (2006) Economic Origins of Dictatorship and Democracy. Cambridge: Cambridge University Press

Blaydes, Lisa and Lo, James. (2011) one man, one vote, one time? A model of democratization in the Middle East. Journal of Theoretical Politics.1-37.

Boix C (2003) Democracy and Redistribution. Cambridge: Cambridge University Press.

Boose, Jason William. (2012) Democratization and Civil Society: Libya, Tunisia and the Arab Spring. International Journal of Social Science and Humanity, Vol. 2, No. 4.pp. 310-315

Galbreath, David J. (2012) Securitizing Democracy and Democratic security: A Reflection on Democratization Studies. Security and Democracy, 8:1, 28-42

Huntington, Samuel, P. (1968) Political Order in Changing Societies. Yale University, pp.4-5

Jaggers, Keith and Tedd Robert, Gurr. (1999) Policy 98 Project Regime Characteristics, 1800-1998. www.bsos.umd.edu/cidcm/polity

Kellogg Institute for International Studies (2012), The Tipping Point: Transition to Democracy in Latin America and the Middle East, University of Notre Dame, p. 14-15

Licklider, Roy. (1998). Civil War Data 2.1 [http//rci.rutgers.edu/ licklide].

Meltzer A and Richards S (1981) A rational theory of the size of government. Journal of Political Economy 89: 914-927.

Miller, Laurel. Martini, Jeffery. Larrabee, Stephen. Rabassa, Angel. Pezard, Stephanie.Taylor, JulieE. Mengistu, Twedaj. (2012). Democratization in the Arab World. Santa Monica: RAND Corporation.

Nickerson, David and Wantchekon. (2001). Opposing Interventions Facilitate Post Civil War Democratization. Working Paper. Yale University.

Padamja, Khandelwal and and Roitman, Augustin. (2013). the Economics of Political Transition: Implications for Arab Spring: Working Paper. 13/69 IMF.

Przeworski, Adam (1991). Democracy and the Market: Political and Economic Reforms in Eastern Europe and Latin America. Cambridge: Cambridge University Press.

Przeworski, Adam. Alvarez, Michael. E., Chibub, Jose Antonio. Limongi, Fernando. (2000). Democracy and Development: political Institutions and Well-Being in The World 1950-1990. Cambridge: Cambridge University Press.

Salame, Ghassan. (1994) Where are the democrats? In: Salame, G (ed.) Democracy without Democrats: The Renewal of Politics in the Muslim World. London: I.B. Tauris.

Stepan, Alfred. And Linz, Juan J. (2013) Democratization Theory and the Arab World. Journal of Democracy, Vol. 24, No. 2, pp. 14-30

Valenzuela, Samuel. (2008) Democratic Consolidation in Post-Transitional Settings: Notion, Process and Facilitating Conditions: Kellogg Institute Working Paper, No. 150.

Völker, Jan. (2012). The BTI 2012: Looking Back on the Arab Spring an Interpretation of Recent Political Development, in (ed), The Arab Spring: One Year After: Europe in Dialogue: 13-36.

Willis, Michael J. (2010). Tunisia: The trailblazer, and The Benchmark, in (ed), The Arab Spring Implications for British Policy: Conservative Middle East Council: 8-12.

Ziblatt, D. (2008) Does landholding inequality block democratization? A test of the 'Bread and Democracy' thesis and the case of Prussia. World Politics 60: 610-641. 